\title{
Talajfizikai jellemzőkből számított megbízhatósági index meghatározása geometriai valószínűségi modell
} alapján

\section{Safety Index Based on Geometric Probability Is Proposed to Represent the Uncertainty of Soil Parameters for Spread Foundations}

\author{
VADAI Zs. ${ }^{1}$, GARAI J. ${ }^{2}$, KovÁCS I. ${ }^{3}$ \\ ${ }^{1}$ University of Debrecen, Faculty of Engineering, Department of Civil Engineering, vadai@eng.unideb.hu \\ 2University of Debrecen, Faculty of Engineering, Department of Civil Engineering, jozsef.garai@fiu.edu \\ 3University of Debrecen, Faculty of Engineering, Department of Civil Engineering, dr.kovacs.imre@gmail.com
}

Absztrakt. A geotechnikában a globális biztonsági tényezőt négy parciális biztonsági tényező szorzataként definiálhatjuk, melynek egyik tagja a talajfizikai jellemzőkből számított biztonsági tényezô. Jelen cikkben bevezetjük a talajfizikai jellemzőkből számított megbízhatósági index fogalmát, bemutatjuk a geometriai valószínúségi modellen alapuló értelmezését és elméleti meghatározásának módját síkalapok esetére, majd értékét tényleges geotechnikai környezetben meg is határozzuk.

Abstract. The overall factor of safety in geotechnics can be defined as the product of four partial factors of safety. One of these partial factors represents the uncertainty of the soil parameters. Based on geometric probability, a safety index is proposed to calculate the uncertainty of the soil parameters for spread foundations. Numerical examples have also been presented.

Kulcsszavak: geotechnika, megbízhatósági, index, geometriai, valószínüség

Keywords: geotechnics, safety, index, geometric, probability

\section{Bevezetés}

Geotechnikai tervezés során a globális geotechnikai biztonsági tényező az alábbi összefüggés alapján határozható meg [1]:

$$
O F S=f_{s}^{(M)} \cdot f_{S}^{(A)} \cdot f_{s}^{(R)} \cdot f_{S}^{(\Delta E R)},
$$

ahol OFS a globális biztonsági tényező, $f_{S}^{(M)}$ az anyagjellemzők biztonsági tényezője, $f_{S}^{(A)}$ a szerkezetre ható terhek biztonsági tényezője, $f_{S}^{(R)}$ a talaj ellenállásának biztonsági tényezője, valamint $f_{S}^{(\Delta E R)}$ a 
kihasználtságból adódó biztonsági tényező. A talajfizikai jellemzők biztonsági tényezőjének meghatározásához a talajfizikai jellemzők karakterisztikus- és várható értékéből számított ellenállások összevetésére van szükség [2] értelmében, hiszen a talajparaméterek parciális biztonsági tényezője az M1 értékcsoportban 1,0. A talajfizikai jellemzők karakterisztikus értékét célszerű úgy származtatni, hogy a vizsgált határállapotot meghatározó kedvezőtlen érték valószínűsége ne legyen nagyobb 5\%-nál [2]. A talajparaméterek várható értéke a minták számtani közepe. Vizsgálatainkat téglalap alakú, vízszintes alapfelületű síkalapokra korlátozzuk, melyek központos függőleges- $V$ és az alapozási síkon átadódó vízszintes $H$ erővel vannak terhelve. Továbbá a $H$ erő az alap $B^{\prime}$ szélességi méretével párhuzamos.

\section{A talajtörési ellenállás meghatározása drénezett viszonyok esetén}

A jelenleg érvényben lévő EC7 szabvány [2] a következő formulát ajánlja a talajtörési ellenállás meghatározására:

$$
c^{\prime} \cdot N_{c} \cdot b_{c} \cdot s_{c} \cdot i_{c}+q^{\prime} \cdot N_{q} \cdot b_{q} \cdot s_{q} \cdot i_{q}+0,5 \cdot \gamma^{\prime} \cdot B^{\prime} \cdot N_{\gamma} \cdot b_{\gamma} \cdot s_{\gamma} \cdot i_{\gamma}=\frac{R}{A^{\prime}} .
$$

A kifejezésben az egységben értendő tagok:

- a talajtörési ellenállás tényezői:

$$
\begin{gathered}
N_{q}=e^{\pi \cdot \operatorname{tg} \varphi^{\prime}} \cdot \operatorname{tg}^{2}\left(45^{\circ}+\frac{\varphi^{\prime}}{2}\right) \\
N_{c}=\left(N_{q}-1\right) \cdot \operatorname{ctg} \varphi^{\prime} \\
N_{\gamma}=2 \cdot\left(N_{q}-1\right) \cdot \operatorname{tg} \varphi^{\prime}
\end{gathered}
$$

- az alapfelület hajlásának tényezői (a bevezetésben tett korlátozó feltételeink alapján):

$$
b_{c}=b_{q}=b_{\gamma}=1
$$

- $\quad$ az alaptest alakjának tényezői (téglalap):

$$
\begin{gathered}
s_{q}=1+\frac{B^{\prime}}{L^{\prime}} \cdot \sin \varphi^{\prime} \\
s_{\gamma}=1-0,3 \cdot \frac{B^{\prime}}{L^{\prime}} \\
s_{c}=\frac{s_{q} \cdot N_{q}-1}{N_{q}-1}
\end{gathered}
$$

- a teher ferdeségének tényezői $H$ vízszintes erő esetén, mely példáinkban az alapozási síkon adódik át:

$$
\begin{gathered}
i_{c}=i_{q}-\frac{1-i_{q}}{N_{c} \cdot \operatorname{tg} \varphi^{\prime}} \\
i_{q}=\left[1-\frac{H}{V+A^{\prime} \cdot c^{\prime} \cdot \operatorname{ctg} \varphi^{\prime}}\right]^{m}
\end{gathered}
$$




$$
\begin{gathered}
i_{\gamma}=\left[1-\frac{H}{V+A^{\prime} \cdot c^{\prime} \cdot \operatorname{ctg} \varphi^{\prime}}\right]^{m+1} \\
m=\frac{2+\frac{B^{\prime}}{L^{\prime}}}{1+\frac{B^{\prime}}{L^{\prime}}}
\end{gathered}
$$

A fenti összefüggésekben $A^{\prime}$ a $B^{\prime}$ hatékony szélességú és $L^{\prime}$ hatékony hosszúságú alaptest alapterülete, $R$ a talajtörési ellenállás és $V$ az alapozási síkon átadódó függőleges erő. Az előző összefüggések tartalmazzák a hatékony súrlódási szöget $\left(\varphi^{\prime}\right)$, a hatékony kohéziót $\left(c^{\prime}\right)$ a hatékony takarási nyomás tervezési értékét az alapsík szintjén $\left(q^{\prime}\right)$ valamint az alapsík alatti talaj térfogatsúlyának tervezési értékét $\left(\gamma^{\prime}\right)$.

\section{Teherbírási vonalak}

A teher ferdeségének tényezőit behelyettesítve a (2) jelű egyenletbe a következő kifejezést kapjuk:

$$
\begin{aligned}
c^{\prime} \cdot N_{c} \cdot b_{c} \cdot s_{c} & \cdot\left[\left(1-\frac{H}{V+A^{\prime} \cdot c^{\prime} \cdot \operatorname{ctg} \varphi^{\prime}}\right)^{m}-\frac{1-\left(1-\frac{H}{V+A^{\prime} \cdot c^{\prime} \cdot \operatorname{ctg} \varphi^{\prime}}\right)^{m}}{N_{c} \cdot \operatorname{tg} \varphi^{\prime}}\right]+q^{\prime} \cdot N_{q} \cdot b_{q} \cdot s_{q} \\
& \cdot\left(1-\frac{H}{V+A^{\prime} \cdot c^{\prime} \cdot \operatorname{ctg} \varphi^{\prime}}\right)^{m}+0,5 \cdot \gamma^{\prime} \cdot B^{\prime} \cdot N_{\gamma} \cdot b_{\gamma} \cdot s_{\gamma} \\
& \cdot\left(1-\frac{H}{V+A^{\prime} \cdot c^{\prime} \cdot \operatorname{ctg} \varphi^{\prime}}\right)^{m+1}=\frac{V}{A^{\prime}}
\end{aligned}
$$

A (3) kifejezés a $V-H$ síkon egy görbe implicit módon adott egyenlete. A pontjai azokat a függőleges $V$ és vízszintes $H$ erők kombinációját jelentik, melyek együttes múködése esetén a talaj szilárdsági teherbírásának a határára kerül. A nyomó erőket pozitív értelműnek véve, az alaptest szimmetria viszonyait szem előtt tartva, elegendő vizsgálatainkat a $V-H$ koordináta rendszer első síknegyedére korlátozni. A vasbeton szilárdságtanban alkalmazott módszerhez hasonlóan, nevezzük a (3) egyenlet által leírt görbét, adott geotechnikai környezetben lévő meghatározott geometriájú síkalap teherbírási vonalának. Attól függően, hogy a (3) egyenletbe a talajparaméterek várható vagy karakterisztikus értékét írjuk, kapjuk a várható- (TVM) vagy karakterisztikus teherbírási vonalat (TVK). (Az M1 értékcsoportban a talajfizikai jellemzők tervezési értékei megegyeznek a karakterisztikus értékekkel.) A teherbírási vonalak alapján elvégezhető az alaptest szilárdsági ellenőrzése. Ha az igénybevételekből kapott egyidejű függőleges és vízszintes erők által meghatározott pontok a teherbírási vonalon, illetve azon belül helyezkednek el az alaptest megfelel, ellenkező esetben pedig nem.

\section{A teherbírási vonal előállítása}

A teherbírási vonal előállítása numerikus szempontból a (3) egyenlet megoldását jelenti. Első lépésben célszerű a $H=0$ esethez tartozó $V_{\max }$ maximális függőleges erőt meghatározni, így előáll a teherbírási vonal és a vízszintes $V$ tengely metszéspontja. A legalább 0 , de a $V_{\text {max }}$-nál kisebb függőleges erőkhöz tartozó $H$ értékek meghatározásához a (3) egyenlet kell megoldani a felvett $V$ erők mellett. Elméletileg 
a görbék szomszédos pontjai közötti távolság a számítógép által kezelni tudott legkisebb értékig csökkenthető. A nemlineáris gyökkereséshez a szabad elérésű Smath Studio Desktop 64-bit 0.99 (build: 7822) programot használtuk.

Az előbbiekből látható, hogy meg tudjuk határozni azoknak a függőleges és vízszintes erőknek a kombinációit, melyek együttes hatására talajtörés következik be, karakterisztikus és átlagos talajfizikai jellemzők esetén.

\section{Az elcsúszási tönkremenetel}

Tudjuk, egy síkalap megfelel elcsúszásra, ha:

$$
H \leq V \cdot \operatorname{tg} \varphi^{\prime} .
$$

A (4) egyenlőtlenség a $V-H$ sík első negyedében, az origóból kiinduló, a $V$ tengellyel $\varphi^{\prime}$ szöget bezáró félegyenes alatti pontok halmazát határozza meg. Az elcsúszási tönkremenetelt is vizsgálhatjuk a hatékony súrlódási szög várható- és karakterisztikus értékére egyaránt. Meghatározható azoknak a függőleges és vízszintes erőknek a kombinációi, melyek együttes hatására az alaptest elcsúszásra nem felel meg, karakterisztikus és átlagos talajfizikai jellemzők esetén.

\section{Kombinált tönkremeneteli mód}

Az alaptesteknek meg kell felelni talajtörés és elcsúszás szempontjából is [3]. Geometriailag ez azt jelenti, hogy a (3) révén meghatározott teherbírási vonal által határolt területnek, valamint a (4) egyenlőtlenségnek megfelelő ponthalmaznak a közös részét kell vennünk. Az így kapott terület határvonalát nevezzük a kombinált tönkremenetelhez tartozó határgörbének. Ha egy $(V ; H)$ igénybevétel pár a határgörbe kerületén, vagy azon belül helyezkedik el, az alaptest ezen igénybevételek egyidejű működése esetén megfelel talajtörés és elcsúszás szempontjából is. (A jelenleg érvényben lévő [2] szabvány szerint akkor felel meg az alaptest, ha a terhek tervezési értékeiből képzett $(V ; H)$ igénybevétel párok a talajparaméterek tervezési értékeiből számított határgörbén, illetve azon belül helyezkednek el.)

\section{Geometriai valószínűségi mező}

Ha egy eseményteret és annak elemeit tudjuk modellezni olyan geometriai objektumokkal, melyeknek mérhető geometriai tulajdonságai vannak és az események valószínűsége egyenesen arányos ezen tulajdonsággal, akkor az eseménytér eseményeivel geometriai valószínűségi mezőt alkot. A valószínűségszámításból ismert tétel szerint, ha az eseménytér mérhető tulajdonsága $T$ és az $A$ esemény geometriai modelljének mérhető tulajdonsága $t$, akkor az $A$ esemény valószínűsége a következő összefüggéssel számítható:

$$
P(A)=\frac{t}{T} .
$$

$T$ és $t$ mennyiségek lehetnek hosszúságok, területek vagy térbeli objektumok esetén térfogatok. 


\section{Az anyagjellemzőkben lévő biztonsági tényező értelmezése}

Az anyagjellemzőkben lévő biztonsági tényező értelmezése a következő kifejezéssel történik:

$$
f_{s}^{(M)}=\frac{R_{m}}{R_{k}}
$$

melyben $R_{k}$ és $R_{m}$ az ellenállások a talajparaméterek karakterisztikus- és várható értékéből számolva. $\mathrm{Az}$ (6) egyenlet alkalmazását az ismert geotechnikai sajátosság teszi nehézkessé, ami szerint az ellenállás értékét befolyásolja a hatás nagysága. Ez mutatkozik meg abban a tényben is, hogy a (3) egyenlet jobb és bal oldalán egyaránt megtalálható a $V$ függőleges erő.

Tekintsük eseménytérnek azt, hogy az alaptest megfelel a talajfizikai jellemzők várható értéke alapján talajtörésre és elcsúszásra egyaránt. Ez geometriailag azt jelenti, hogy az alaptestre átadódó egyidejű függőleges és vízszintes erők a várható értékekből számított, kombinált tönkremenetelhez tartozó határgörbe kerületén vagy azon belül helyezkednek el. Geometriai valószínűségi modellt alkalmazva, annak a valószínűsége, hogy az alaptest a talajparaméterek karakterisztikus értéke alapján megfelel talajtörés és elcsúszás szempontjából, azaz, hogy az egyidejű igénybevételek a karakterisztikus jellemzőkből számított határgörbén, illetve azon belül helyezkednek el, a karakterisztikus- és a várható értékekből számított határgörbék által határolt területek arányával egyenlő. Feltéve, hogy bármely $(V ; H)$ igénybevétel pár a görbéken belül azonos valószínűséggel fordulhat elő. Az előbbi valószínűség reciprok értékét nevezzük a kombinált tönkremenetelhez tartozó megbízhatósági indexnek:

$$
I_{\text {conf }}=\frac{A_{m}}{A_{k}},
$$

A (7) egyenlet jobb oldalán a számlálóban a talajparaméterek várható értékei alapján meghatározott határgörbe alatti terület $\left(A_{m}\right)$, míg a nevezőben a karakterisztikus jellemzőkből számított határgörbe alatti terület $\left(A_{k}\right)$ van.

\section{Numerikus példa}

Ebben a pontban bemutatjuk az 1. táblázatban megadott geotechnikai környezetben elhelyezkedő, az 1. ábrán látható A1 jelű alaptest esetén a talajtöréshez és a kombinált tönkremenetelhez tartozó megbízhatósági index fentiek alapján történő számításának eredményeit. 
International Journal of Engineering and Management Sciences (IJEMS) Vol. 6. (2021). No. 3

DOI: $10.21791 /$ IJEMS.2021.3.4.

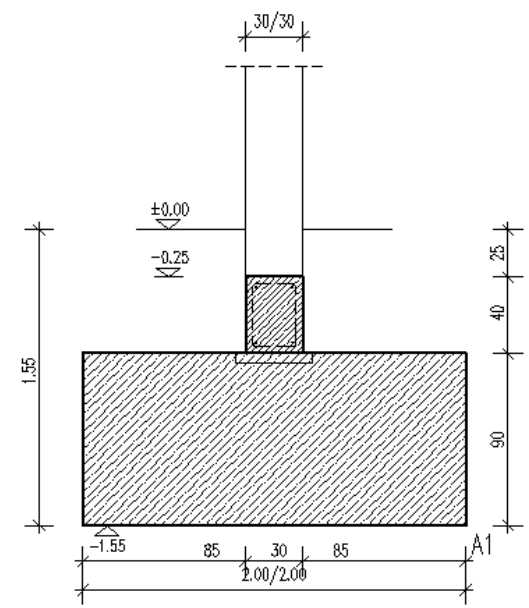

1. ábra: A1 alaptest

\begin{tabular}{|c|c|c|c|}
\hline & $\varphi^{\prime}\left[{ }^{\circ}\right]$ & $\mathrm{c}^{\prime}[\mathrm{kPa}]$ & $\mathrm{E}_{\mathrm{s}}{ }^{\prime}\left[\mathrm{MN} / \mathrm{m}^{2}\right]$ \\
\hline \hline \multirow{2}{*}{$\begin{array}{c}\text { Átlag érték }\left(\mathrm{X}_{\mathrm{m}}\right) \\
\text { Statisztikai értékelés } \\
{[4] \text { alapján }}\end{array}$} & 26,5 & 23,7 & 6,3 \\
\cline { 2 - 4 } & \multicolumn{3}{|c|}{ Geotechnikai paraméterek karakterisztikus értékei } \\
\hline Értékcsoport & 24,4 & 17,7 & 6,0 \\
\hline M1 & Geotechnikai paraméterek tervezési értékei $\left(\mathrm{X}_{\mathrm{d}}\right)$ \\
\hline
\end{tabular}

1. táblázat: Talajparaméterek átlag (várható) és karakterisztikus értéke

A hatékony takarási nyomás tervezési értéke az alapsík szintjén $q^{\prime}=28,36 \frac{\mathrm{kN}}{\mathrm{m}^{2}}$ és az alapsík alatti talaj térfogatsúlyának tervezési értéke $\gamma^{\prime}=18,30 \frac{\mathrm{kN}}{\mathrm{m}^{3}}$.

\subsection{A talajparaméterek várható értékeivel végzett számítások eredményei}

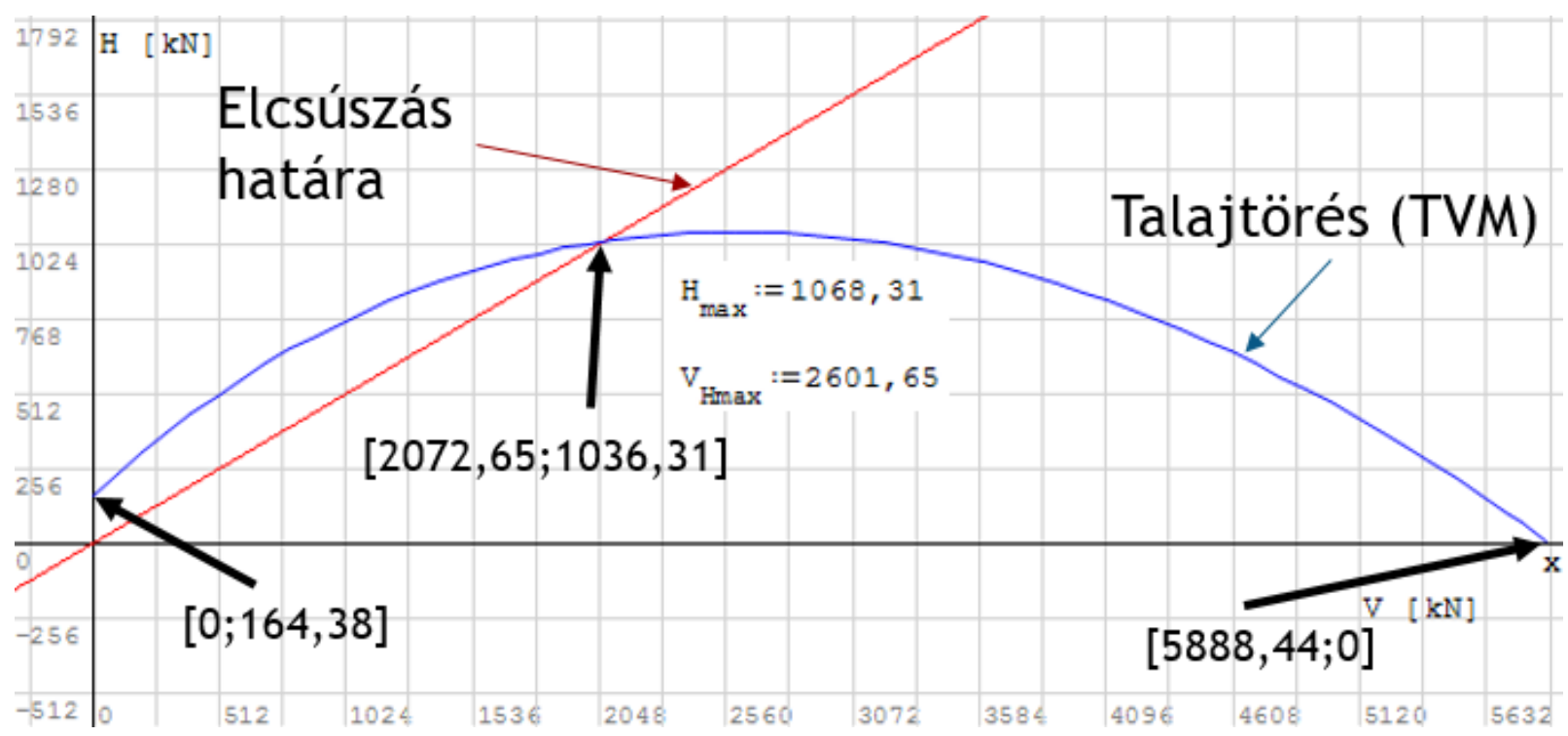

2. ábra: Teherbírási vonal (TVM) és az elcsúszás határa a talajparaméterek várható értéke alapján 


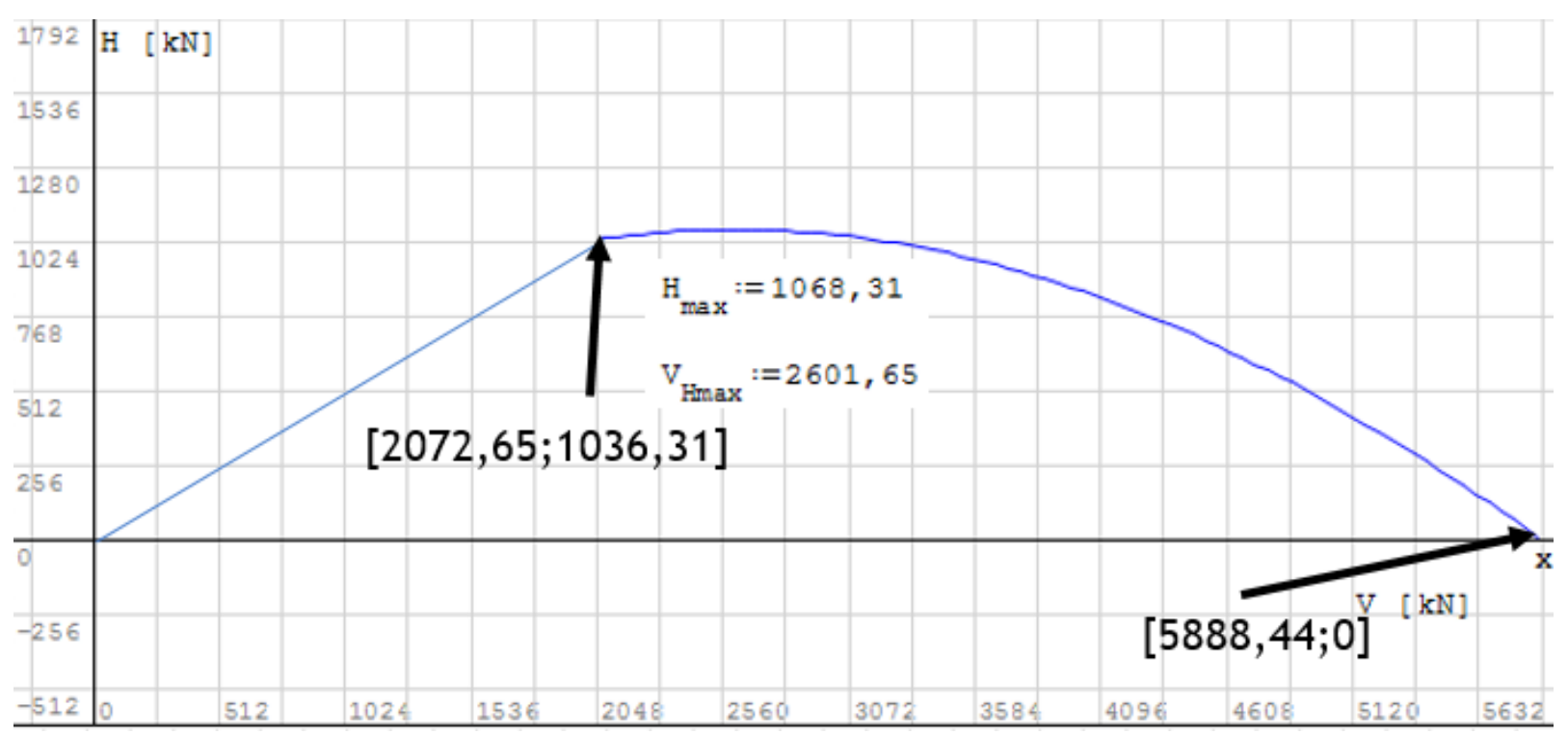

3. ábra: Határgörbe a talajparaméterek várható értéke alapján

7.2. A talajparaméterek karakterisztikus értékeivel végzett számítások eredményei

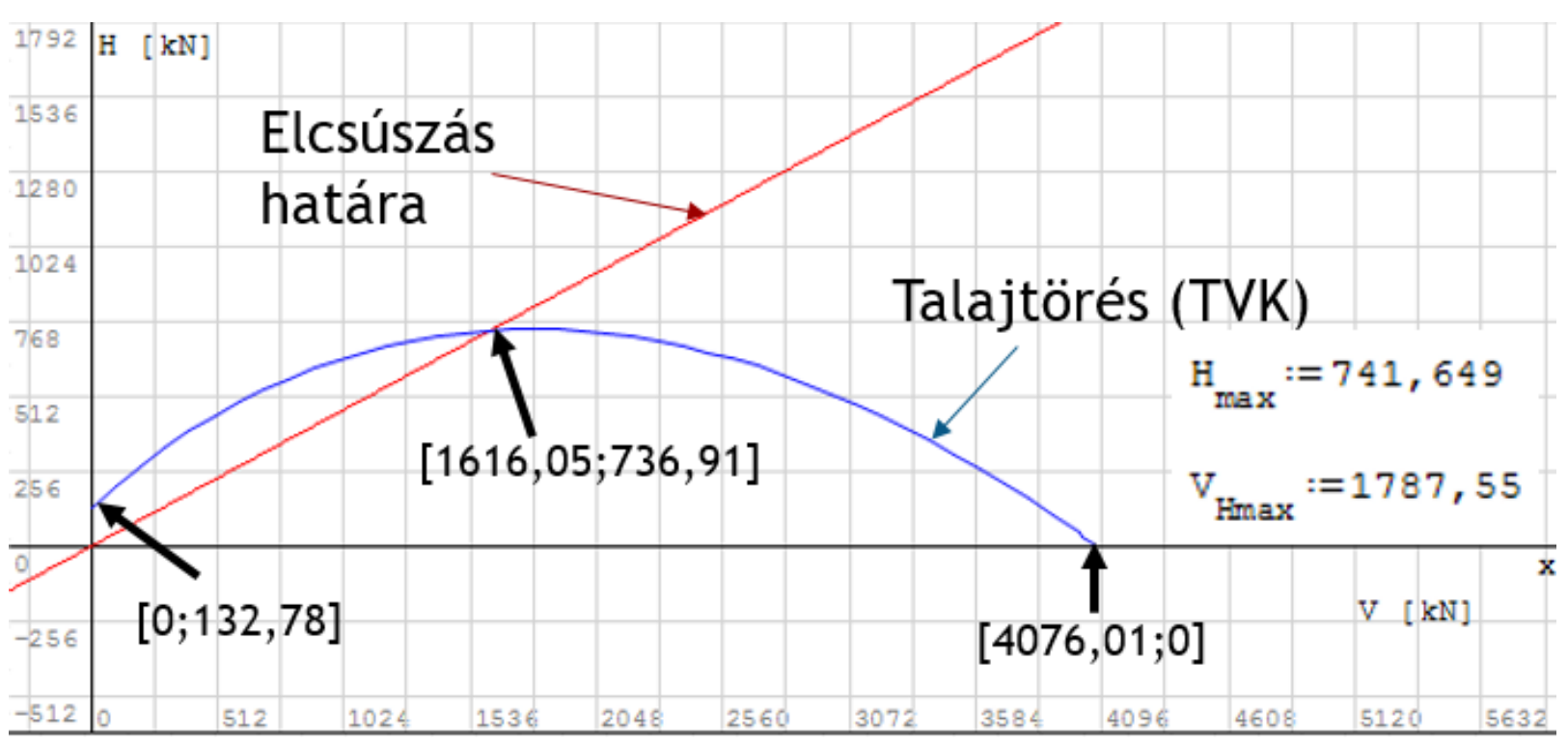

4. ábra: Teherbírási vonal (TVK) és az elcsúszás határa a talajparaméterek karakterisztikus értéke alapján 


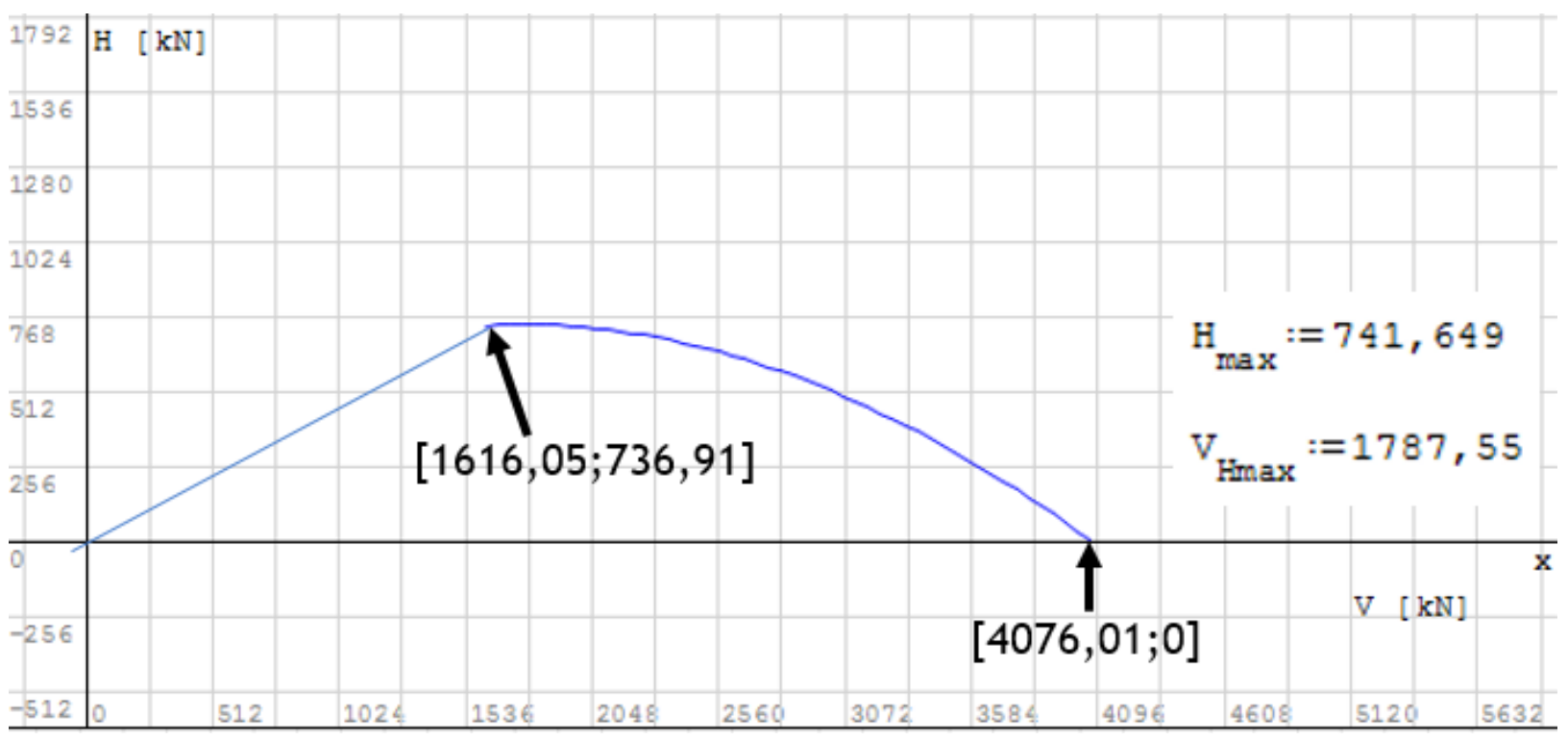

5. ábra: Határgörbe a talajparaméterek karakterisztikus értéke alapján

7.3. A talajparaméterek várható- és karakterisztikus értékével végzett számítások eredményeinek összevetése

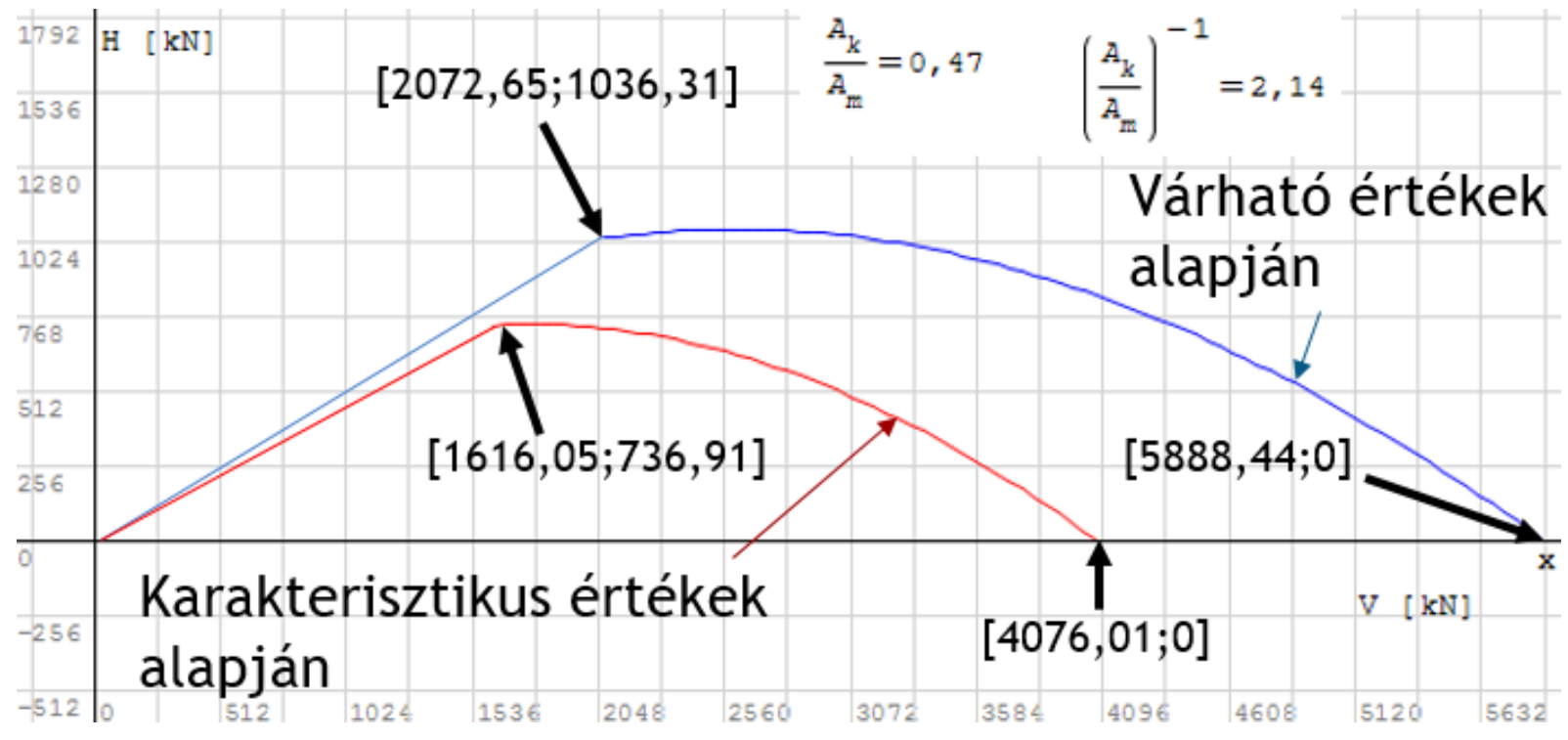

6. ábra: A várható- és a karakterisztikus értékek alapján számított határgörbék összevetése

A 6. ábrán látható görbék alatti területek, $A_{m}=3941700 k N^{2}$ (várható értékekből) és $A_{k}=$ $1838000 k N^{2}$ (karakterisztikus értékekből), melyekből számítható a kombinált tönkremeneteli módhoz tartozó megbízhatósági index a (7) összefüggés felhasználásával:

$$
I_{\text {conf }}=\frac{A_{m}}{A_{k}}=2,14 \text {. }
$$




\section{További számítások eredményei}

A 7. fejezetben bemutatott eljárással meghatároztuk az 1. táblázatban megadott geotechnikai környezetben lévő, különböző geometriájú alaptestek esetén adódó megbízhatósági indexet. A számítások eredményeit a következő táblázatok tartalmazzák.

\begin{tabular}{|c|c|c|c|c|c|}
\hline $\begin{array}{c}\mathrm{B} \\
{[\mathrm{m}]}\end{array}$ & $\begin{array}{c}\mathrm{L} \\
{[\mathrm{m}]}\end{array}$ & $\begin{array}{c}\mathrm{A}_{\mathrm{m}} \\
{\left[\mathrm{kN}^{2}\right]}\end{array}$ & $\begin{array}{c}\mathrm{A}_{k} \\
{\left[\mathrm{kN}^{2}\right]}\end{array}$ & $\boldsymbol{I}_{\text {conf }}$ & $A_{k} / A_{m}$ \\
\hline \hline 2 & 2 & 3941700 & 1838000 & $\mathbf{2 , 1 4 5}$ & 0,466 \\
\hline 2 & 1,5 & 2677300 & 1233700 & $\mathbf{2 , 1 7 0}$ & 0,461 \\
\hline 2 & 1 & 1648500 & 746040 & $\mathbf{2 , 2 1 0}$ & 0,453 \\
\hline 2 & 0,5 & 858690 & 375620 & $\mathbf{2 , 2 8 6}$ & 0,437 \\
\hline
\end{tabular}

2. táblázat: Megbízhatósági index B×L méretü pontalapok esetében.

A 2. táblázat alapján megfigyelhető, hogy a pontalapok esetében a megbízhatósági index nő a vízszintes erőre merőleges alaprajzi méret csökkenésével.

\begin{tabular}{|c|c|c|c|c|}
\hline $\begin{array}{c}\mathrm{B} \\
{[\mathrm{m}]}\end{array}$ & $\begin{array}{c}\mathrm{A}_{\mathrm{m}} \\
{\left[\mathrm{kN}^{2}\right]}\end{array}$ & $\begin{array}{c}\mathrm{A}_{k} \\
{\left[\mathrm{kN}^{2}\right]}\end{array}$ & $\boldsymbol{I}_{\text {conf }}$ & $A_{k} / A_{m}$ \\
\hline \hline 1 & 10898000 & 5297100 & $\mathbf{2 , 0 5 7}$ & 0,486 \\
\hline 0,75 & 5722800 & 2782800 & $\mathbf{2 , 0 5 6}$ & 0,486 \\
\hline 0,5 & 2366600 & 1151800 & $\mathbf{2 , 0 5 5}$ & 0,487 \\
\hline
\end{tabular}

3. táblázat: Megbízhatósági index B szélességú sávalapok esetében

\section{9. Összefoglalás}

A geometriai valószínűség alapján bevezetett megbízhatósági index az alaptest méretét, alakját és geotechnikai környezetét együttesen jellemzi. Komplex módon tudjuk kezelni a talajtörés és az elcsúszás miatti tönkremenetelt. A megbízhatósági index mértéke vizuálisan megjeleníthető a kombinált tönkremenetelhez tartozó határgörbékkel (6. ábra), melyeket a teherbírási vonalak elcsúszási feltétellel való módosításaival kapunk. Tartószerkezeti tervezés során, hatékony módszer a határgörbék alkalmazása, mely segítségével adott $(V ; H)$ igénybevétel párok esetén megállapítható, hogy az alaptest méretei megfelelnek-e az adott geotechnikai környezetben. Két, a szilárdsági- és az elcsúszási feltételnek megfelelő, különböző geometriájú alaptest közötti választás esetén, a gazdasági szempont mellett, a megbízhatósági index is segítheti szerkezettervező mérnök döntését 
International Journal of Engineering and Management Sciences (IJEMS) Vol. 6. (2021). No. 3

DOI: 10.21791/IJEMS.2021.3.4.

\section{Hivatkozások}

[1] Garai, J., Vadai, Z. and Kovács, I. (2019) Globális biztonsági tényező. Geotechnika 2019 Konferencia Velence. Available at: https://drive.google.com/file/d/1NabSujaDi_kP4p9k4624hWX16H2FuWLz/view (Accessed: 8 October 2021).

[2] MSZ EN 1997-1:2006 (2006)

[3] Varga, L. (1962) 'Alapok elcsúszásának vizsgálat', Mélyépítéstudományi Szemle, 12(6), pp. 270270.

[4] Schneider H. R. (1999): Definition and determination of characteristic soil properties. Proceedings of the fourteenth international conference on soil mechanics and foundation engineering Hamburg. pp. 2271-2278 